\title{
PERAN PEMERINTAH DESA DALAM PENANGGULANGAN KEJAHATAN (Studi Di Desa Nowa Kecamatan Woja Kabupaten Dompu)
}

\author{
Aman Ma'arij \& Gufran \\ Program Studi Ilmu Hukum, Sekolah Tinggi Ilmu Hukum Muhammadiyah Bima \\ E-mail: amanmarijstih@gmail.com \& azisgufran@gmail.com
}

\begin{abstract}
Crime is a bad act, derived from the word evil which means very bad, very bad, very bad, while juridically crime is defined as an act that violates the law or is prohibited by law in the first problem research what is the cause of crime in Indonesia? Nowa Village, Woja District, Dompu Regency and how is the role of the nowa village government in overcoming crimes such as gambling, conflict and other crimes. The purpose of this study was to find out how the role of the village government in overcoming crime in the village of Nowa, Woja sub-district, Dompu district and the factors that influence the occurrence of crime in Nowa Village, Woja District, Dompu Regency, this study used empirical research methods using the approach of legislation, sociology and cases. The results showed that the role of the village government in tackling crime in the nowa village was to carry out socialization at the hamlet level and strengthen coordination between agencies, both from the village government and law enforcement officers (police) and the factor that influenced the occurrence of crime in nowa village was the level of youth promiscuity. , Brutal Archery, Rampant Distribution of Alcohol and Drugs, Legal Gambling, and Brawls Between Youth.
\end{abstract}

Keywords: Village Government, Countermeasures, Crime, Dompu.

\begin{abstract}
Abstrak
Kejahatan merupakan suatu perbuatan yang buruk, berasal dari kata jahat yang memiliki arti sangat tidak baik, sangat buruk, sangat jelek, sedangkan secara yuridis kejahatan diartikan sebagai suatu perbuatan melanggar hukum atau yang dilarang oleh undang-undang dalam penelitian masalah pertama apakah Penyebab Terjadinya Kejahatan Di Desa Nowa Kecamatan Woja Kabupaten Dompu dan bagaimana peran pemerintah desa nowa dalam penanggulangan kejahatan seperti, perjudian, konflik dan kejahatan lainya. Tujuan penelitian ini untuk mengetahui bagaimana peran pemerintah desa dalam penanggulangan kejahatan di desa nowa kecamatan woja kabuapten dompu dan faktor-faktor yang mempengaruhi terjadinya kejahatan di Desa Nowa Kecamatan Woja Kabupaten Dompu, penelitian ini menggunakan metode penelitian empiris dengan menggunakan pendekatan Peraturan perundang-undangan, sosiologi dan kasus. Hasil penelitian menunjukan bahwa Peran Pemerintah Desa dalam menanggulangi kejahatan di desa nowa adalah dengan Melakukan sosialisasi tingkat dusun dan Memperkuat koordinasi antara instansi, baik dari pemerintah desa dengan aparat penegak hukum (kepolisian) dan Faktor yang mempengaruhi terjadinya kejahatan di desa nowa adalah tingkat pergaulan bebas pemuda, Pemanahan Secara Brutal, Penyebaran Miras dan Narkoba Yang merajalela, Perjudian Legal, dan Tawuran antara Pemuda.
\end{abstract}

Kata Kunci: Pemerintah Desa, Penangguangan, Kejahatan, Dompu

\section{PENDAHULUAN}

Pada era globalisasi, dinamika pertumbuhan budaya dan pesatnya perkembangan ilmu pengetahuan dan teknologi, melahirkan persaingan dalam berbagai hal dalam kehidupan manusia, seperti ideologi, sosial, ekonomi, seni, etika, maupun moral. Banyak perubahan yang terjadi pada nilai-nilai yang terkandung didalamnya, seperti materialisme, hedonisme dan lain sebagainya. Hal ini juga mengakibatkan perubahan nilai yang terdapat dalam kemasyarakatan. Perubahan tersebut juga berdampak pada perilaku manusia. Perubahan positif tentu saja sangat menguntungkan masyarakat, tetapi perubahan negatif dapat menyebabkan keresahan dalam kehidupan masyarakat sebagai akibat manusia yang berperilaku negatif, seperti melakukan tindakan kejahatan.

Kejahatan merupakan suatu perbuatan suatu tindakan yang secara umum memiliki arti perbuatan yang tidak sesuai dengan hukum yang berlaku (Suharso dan Ana Retnoningsih, 2011: 196). Fenomena kejahatan ada tiga aliran pemikiran, yaitu kriminologi klasik bahwa kejahatan dan penjahat pada umumnya dipandang dari sudut hukum artinya kejahatan adalah perbuatan yang dilarang oleh undangundang dan penjahat adalah orang yang melakukan kejahatan, kriminologi positivis yaitu mengarahkan usaha untuk menganalisis sebab-sebab prilaku kejahatan melalui studi 
ilmiah, dan kriminologi kritis yaitu tidak berusaha menjawab persoalan-persoalan apakah prilaku manusia bebas ataukah ditentukan, akan tetapi lebih mengarahkan pada proses-proses yang dilakukan oleh manusia dalam membangunan dunianya dimana dia hidup. (Muliadi, Saleh. 2015:346)

Penyalahgunaan narkotika, obat-obat berbahaya (narkoba) dan minuman keras di Indonesia beberapa tahun terakhir ini menjadi masalah serius dan telah mencapai masalah keadaan yang memperihatinkan sehingga menjadi masalah Nasional. Korban penyalahgunaan narkoba dan minuman keras telah meluas sedemikian rupa sehingga melampaui batas-batas strata sosial, umur, jenis kelamin. Merambah tidak hanya perkotaan tetapi merambah sampai pedesaan dan melampaui batas negara yang akibatnya sangat merugikan perorangan, masyarakat, negara, khususnyagenerasi muda.

Berdasarkan Data statistik dari Kapolsek Woja mengenai tindak pidana di Kecematan Woja dalam bentuk Table:

\begin{tabular}{|c|c|c|c|}
\hline No & Tahun & Jenis & Jumlah \\
\hline 1. & $2016-$ & $\begin{array}{c}\text { Kasus } \\
\text { Tidak } \\
\text { Pidana }\end{array}$ & 125 Kasus \\
\hline 2. & $\begin{array}{c}2017- \\
2018\end{array}$ & $\begin{array}{c}\text { Kasus } \\
\text { Tindak } \\
\text { Pidana }\end{array}$ & 98 kasus \\
\hline 3. & $2018-$ & $\begin{array}{c}\text { Kasus } \\
\text { Tindak } \\
\text { Pidana }\end{array}$ & 83 kasus \\
& 2019 & $\begin{array}{c}\text { Kasus } \\
\text { Tindak } \\
\text { Pidana }\end{array}$ & 194 kasus \\
\hline 4. & $2019-$ & $\begin{array}{c}\text { Kasus } \\
\text { Tindak } \\
\text { Pidana }\end{array}$ & 73 Kasus \\
\hline 5. & 2020 & $\begin{array}{c}\text { Kasus } \\
\text { tindak } \\
\text { Pidana }\end{array}$ & 15 Kasus \\
& 2021 & Masih \\
& $2021-$ & Berjalan \\
\hline 6. & 2022 & & \\
\hline
\end{tabular}

Sumber : Polsek Woja Tahun 2021

Beberapa faktor pemicu lahirnya sebuah kejahatan Di Desa Nowa Kecematan Woja ialah tingkat pergaulan Bebas yang tinggi. Beberapa tindak Kejahatan terjadi ditengah-tengah masyarakat, terutama ditingkat pergaulan bebas pemuda yang ada di Desa Nowa itu sendiri, contoh beberapa Kasus yang terjadi di Desa nowa pertama adalah Pemanahan Secara Brutal, Penyebaran Miras dan Narkoba Yang merajalela, Perjudian Legal, dan Tawuran antara Pemuda. Sehingga beberapa masalah muncul dengan berentetan dari masalah-masalah awal yang timbul yang disebabkan oleh faktor-faktor diatas (Hasil Wawancara Dengan Bapak Ipda Zainal Arifin Kapolsek Woja Kabupaten Dompu, 2021).

Maka oleh demikian Peran pemerintah Desa dalam menangani masalah ini sangatlah perlu dilakukan, dikarenakan pemerintah desa lah yang secara langsung bersentuhan dengan masyarakat nya. Jika dikaitkan dengan prinsip utama dalam mengembangkan konsep pemberdayaan masyarakat maka peran pemerintah desa adalah Sumber Solusi dalam melaksanakan penyeimbangan hukum. Maka desa dengan beberapa program produktif nya bisa mengalihkan aktifitas pemuda dari yang negatif menjadi aktifitas positif dan akan menekan angka kriminalitas di desa Nowa. Dengan adanya pendekatan dari bawah maka Pemerintah Desa berfungsi sebagai pengontrol, pelaksanaan program-program serta ikut menjadi agen perubahan untuk generasi.

\section{METODE}

Jenis penelitian ini adalah penelitian empiris, yaitu penelitian denganadanya data-data lapangan sebagai sumber data utama, seperti hasil wawancara dan observasi. Penelitian empiris digunakan untuk menganalisis hukum yang dilihat sebagai prilaku masyarakat yang berpola dalam kehidupan masyarakat yang selalu berinteraksi dan berhubungan dalam Aspek Kemasyarakatan (Bambang Sunggono, (2003:43). Pendekatan yang digunakan adalah kualitatif yaitusuatu cara analisis hasil penelitian yang menghasilkan data deskriptif analitis, yaitu data yang dinyatakan secara tertulis atau lisanserta juga tingkah laku yang nyata, yang diteliti dan dipelajari sebagaisesuatu yang utuh. (Mukti Fajar ND dan Yulianto Achmad, (2010: 192)

Sumber data yang digunakan dalam penelitian empiris adalah sebagai berikut pertama Data Primer, Data yang diperoleh secara langsung dari sumber utama seperti perilaku warga masyarakat yang dilihat melalui 
penelitian. (Soerjono Soekanto, (2014:25), yaitu: kepala desa, tokoh pemuda, tokoh masyarakat, tokoh agama, bhabinsa dan bhabinkamtibmas. Kedua Data Sekunder adalah Data-data yang diperoleh dari sumber kedua yang merupakan pelengkap. Seperti: undang-undang, jurna, tesis, disertasi dan lain-lain.

Sementara Teknik Pengumpulan Data yakni merupakan teknik yang digunakan untuk mengumpulkan dari salah satu atau beberapa sumber data yang telah ditentukan. Dalam penelitian ini digunakan metode wawancara yaitu jalan mendapatkan informasi dengan cara bertanya langsung kepada responden. Kemudian Teknik Analisis Data digunakan penulis adalah deskriptif kualitatif, yaitu analisis yang menggambarkan keadaan atau status fenomena dengan kata-kata atau kalimat, kemudian dipisahkan menurut kategorinya untuk memperoleh kesimpulan. Dalam mengolah data atau proses analisisnya, penulis menyajikan terlebih dahulu data yang diperoleh dari lapangan atau dari wawancara.

\section{HASIL DAN PEMBAHASAN}

Tindak Kejahatan hampir setiap hari terjadi dimana pun, terutama di desa-desa padat penduduk seperti Nowa, Baka Jaya, bara, Una, Kendai II, Simpasai, Renda, dan Monta. Berita tentang tindakan kejahatan sudah menjadi berita sehari-hari warga Dompu. Seperti misalnya peristiwa seperti pembunuhan, pemanahan brutal, tawuran antara pemuda, pembacokan dan masih banyak lagi. Hal tersebut merupakan tindakan yang merugikan orang lain dan para pelaku dari tindakan-tindakan kejahatan tersebut wajib diberikan hukuman yang sepadan atas apa yang ia lakukan.

Tindakan kejahatan merupakan tindakan yang melanggar norma atau hukum. Tindak kejahatan dapat dilakukan oleh siapapun dan dimanapun, tua, remaja, bahkan anakanak. Tindakan kejahatan terjadi disebabkan beberapa faktor, pertama adalah faktor sosial, kondisi sosial yang buruk dapat menjadi faktor penyebab terjadinya tindak kejahatan dimasyarakat, sementara kondisi sosial yang baik akan menciptakan kondisi yang baik pula dapat meminimalisir angka kejahatan. Kedua adalah faktor ekonomi, faktor ekonomi memang menjadi alasan yang sering atas terjadinya tindakan kriminalitas tersebut, terkadang karena alasan ekonomi untuk memenuhi kebutuhannya orang rela melakukan tindakan menyimpang ini dengan cara melanggar norma hukum dan moral. Terakhir adalah budaya, karena perbedaan budaya ras atau suku bangsa terkadang adanya perselisihan siapa yang paling unggul, perbedaan budaya memang dapat menimbulkan adanya konflik hingga terjadinya tindak kriminalitas berupa konflik antar kelompok.

Perilaku jahat yang ada dalam masyarakat merupakan hal yang menarik untuk dibicarakan. Sisi yang menarik bukan saja karena pemberitaan tentang berbagai perilaku manusia yang ganjil dan dapat mendongkrak olah media massa dan rating dari suatu mata acara di stasiun televisi, tetapi juga karena tindakan menyimpang dianggap dapat mengganggu ketertiban masyarakat. (Djamal, S.F., 2019: 230)

Kejahatan bukanlah sebuah istilah yang asing lagi, khususnya bagi masyarakat Indonesia. Semakin meningkatnya praktik kejahatan disusul dengan semakin maraknya pemberitaan terhadap kasus kriminalitas, baik melalui media elektronik hingga persepsipersepsi dari kalangan masyarakat menjadikannya sebagai suatu topik yang seakan-akan tidak pernah habis dan bosan untuk dibahas, begitu pula dengan para pelaku kriminalitas justru semakin bertambah dengan berbagai macam pola dan model kejahatan yang dilakukan. Hingga saat ini sudah tidak terhitung lagi berapa jumlah tindak kriminalitas yang terjadi di Indonesia. Berbagai tindak pidana pun dilakukan mulai dari pemerkosaan, pencurian motor, perampokkan, ranjau paku, pencurian. Para pelaku pun merasa tak bersalah dengan apa yang meraka lakukan pada orang lain. Kriminalitas merupakan salah satu bentuk penyakit sosial yang memang sulit untuk diatasi, sebab kriminalitas bukanlah suatu hal yang pasti, bisa terjadi pada siapapun dengan usia yang tidak tertentu. Terkadang mereka melakukannya secara sadar ataupun tidak sadar karena dipaksa oleh sesuatu, situasi dan kondisi tertentu. 


\section{Penyebab Terjadinya Kejahatan Di Desa Nowa Kecamatan Woja Kabupaten Dompu}

Kejahatan masih menjadi ancaman terbesar bagi rasa aman manusia untuk berkehidupan dalam perubahan-perubahan yang terjadi pada nilai-nilai kemasyarakatan. Rasa aman juga merupakan salah satu hak asasi manusia, sehingga baik pemerintah maupun masyarakat itu sendiri harus saling berkerja sama untuk mengurangi jumlah kejahatan di Indonesia (Prakoso, Abintoro. 2013: 79).

Tindak Kejahatan hampir setiap hari terjadi dimana pun, terutama di desa-desa padat penduduk seperti Nowa, Baka Jaya, bara, Una, Kendai II, Simpasai, Renda, dan Monta. Berita tentang tindakan kejahatan sudah menjadi berita sehari-hari warga Dompu.Seperti misalnya peristiwa seperti pembunuhan, pemanahan brutal, tawuran antara pemuda, pembacokan dan masih banyak lagi. Hal tersebut merupakan tindakan yang merugikan orang lain dan para pelaku dari tindakan-tindakan kejahatan tersebut wajib diberikan hukuman yang sepadan atas apa yang ia lakukan.

Tindakan kejahatan merupakan tindakan yang melanggar norma atau hukum. Tindak kejahatan dapat dilakukan oleh siapapun dan dimanapun, tua, remaja, bahkan anakanak. Tindakan kejahatan terjadidisebabkan beberapa faktor, pertama adalah faktor sosial,kondisi sosialyang buruk dapat menjadi faktor penyebab terjadinya tindak kejahatan dimasyarakat, sementara kondisi sosial yang baik akan menciptakan kondisi yang baik pula dapat meminimalisir angka kejahatan. Kedua adalah faktor ekonomi, faktor ekonomi memang menjadi alasan yang sering atas terjadinya tindakan kriminalitas tersebut, terkadang karena alasan ekonomi untuk memenuhi kebutuhannya orang rela melakukan tindakan menyimpang ini dengancara melanggar norma hukum dan moral. Terakhir adalah budaya, karena perbedaan budaya ras atau suku bangsa terkadang adanya perselisihan siapa yang paling unggul, perbedaan budaya memang dapat menimbulkan adanya konflik hingga terjadinya tindak kriminalitas berupa konflik antar kelompok.

Kejahatan bukanlah sebuah istilah yang asing lagi, khususnya bagi masyarakat
Indonesia. Semakin meningkatnya praktik kejahatan disusul dengan semakin maraknya pemberitaan terhadap kasus kriminalitas, baik melalui media elektronik hingga persepsipersepsi dari kalangan masyarakat menjadikannya sebagai suatu topik yang seakanakan tidak pernah habis dan bosan untuk dibahas, begitu puladengan para pelaku kriminalitas justru semakin bertambah dengan berbagai macam pola dan model kejahatan yang dilakukan. Hingga saat ini sudah tidak terhitung lagi berapa jumlah tindak kriminalitas yang terjadi di Indonesia.Berbagai tindak pidana pun dilakukan mulai dari pemerkosaan, pencurian motor, perampokkan, ranjau paku, pencurian. Para pelaku pun merasa tak bersalah dengan apa yang meraka lakukanpada orang lain.

Penyebab adanya tindak kriminalitas biasanya disebabkan olehbeberapa faktor, yang pertama adalah faktor sosial, kondisi sosial yang buruk dapat menjadi faktor terjadinya tindak kriminalitas dimasyarakat, sementara kondisi sosial yang baik akan menciptakan kondisi yang baik pula dapat meminimalisir angka kejahatan. Yang kedua adalah faktor ekonomi, faktor ekonomi memang sering menjadi alasan utama atau akar dari tindak kriminalitas. Terkadang karena alasan ekonomi untuk memenuhi kebutuhannya orang rela melakukan tindakan menyimpang ini dengan cara melanggar norma hukum dan moral. Yang ketiga adalah budaya, karena adanya perbedaan budaya dan ras atau suku bangsa terkadang kita bersilisih siapa yang paling hebat serta paling unggul perbedaan budaya memang dapat menimbuklan konflik berawal dari cek cok atau masalah kecil hingga menjadi tindak kriminalitas berupa konflik antar kelompok. Yang terakhir adalah hawa nafsu yang tak terkendali akan sesuatu, maksudnya adalah Biasanya saat seseorang sangat menginginakan sesuatu maka berbagai-bagai cara ditempuh untuk mewujudkan hal tersebut. Bahkan bisabisa sampai menghalalkan segala cara, misalnya saja adalah dengan mencuri. Tetapi manusia yang bijak akan mengikatkeliaran hawa nafsunya itu dengan senantiasa memusatkan pikiran kepada Tuhan dalam doa, firman dan nyanyian pujian yang bersifat terus-menerus. 
Salah satu jenis kejahatan yang ada di desa Nowa atau terbilang sangat sering terjadi adalah pemanahan brutal, dalam aksi pemanahan brutal ini pelaku tanpa ada sedikitpun rasa kasihan dalam melakukan tindakan amoral, karena kasus ini sangat membuat warga sangat resahkan masyarakat meski duduk didepan rumahnya sendiri. Kondisi ini sangat membuat warga desa nowa merasa takut jikaberkumpul disaat malam hari apalagi rumah yang ia tempati merupakan kawasan yang sangat terkenal dengan tindak kejahatannya sangat tinggi. Perilaku anak-anak dan remaja menunjukkan tanda-tanda kurang atau tidak adanya konformitas terhadap normanorma sosial. Anak-anak dan remaja yang melakukankejahatan itu pada umumnya kurang memiliki kontrol diri, atau justru menyalahgunakan kontrol diri tersebut, dan suka menegakkan standar tingkah laku sendiri, di samping meremehkan keberadaan orang lain. Kejahatan yang mereka lakukan itu pada umumnya disertai unsur-unsur mental dengan motif motif subyektif, yaitu untuk mencapai satu objek tertentu dengan disertai kekerasan.Pada umumnya anak-anak dan remaja serta pemuda tersebut sangat egoistis, dan suka sekali menyalahgunakan dan melebih-lebihkan harga dirinya. Maka dari itu dengan adanya tindak kriminalitas ini seharusnya ada kerja sama antara masyarakat di Desa Nowa, polisi dan pemerintah, agar tindak kejahatan itu tidak terulang atau terjadi lagi dan meresahkan masyarakat desa nowa lagi. (Hasil wawancara dengan Serda Sudirman (Babinsa Desa Nowa) dan AIPDA Dahlan (Bhabinkantibmas Desa Nowa) pada Hari Senin, Tanggal 23 Agustus 2021 pada jam 11:00 WITA)

\section{Peran Pemerintah Desa Dalam Penanggulangan Kejahatan Di Desa Nowa Kecamatan Woja Kabupaten Dompu}

Beberapa Upaya yang dilakukan oleh pemerintah setempat dalam menekan angka kriminalitas di Desa Nowa Kecematan Woja Kabupaten Dompu:

a. Melakukan sosialisasi tingkat dusun, dimana sosialisasi itu dilakukan agar seluruh masyarakat memiliki rasa kepedulian dan kerjasama dalam membangun hubungan koordinasi yang masif untuk seluruh masyarakat di desa Nowa, apapun yang dilihat dan dirasakan mengancam bagi Masyarakat agar segra melaporkan kepada babinsa dan bhabinkamtibmas desa Nowa. Sosialisasi itu dilakukan pada saat musyawarah masyarat (mbolokampo);

b. Memperkuat koordinasi antara instansi, baik dari pemerintah desa dengan aparat penegak hukum (kepolisian), agar terjaganya keamanan dan ketertiban di lingkunan Desa Nowa. Yang mana Kapolsek Woja bertempat di Desa Nowa itu sendiri sehingga koordinasi Pemerintah Desa Nowa dengan Aparatur kepolisian cepat;

c. Pembinaan keolahragaan untuk pemuda di tingkat desa baik dalam bidang Olahraga Sepak Bola dan Volly Ball, karena Pemerintah Desa Nowa melirik beberapa potensi pemudanya adanya kegiatan olahraga juga dapat mengurangi aktifitas negatif di tingkat pergaulan pemudanya;

d. Pembangunan lapangan sepak bola dan lapangan volly ball di lapangan desa nowa, sebagai titik sentral kegiatan pemuda, sehingga dapat mengontrol baik potensi dan pergaulan pemudanya. (Hasil Wawancara Dengan Bapak Muhammad Amin, S.sos. (Sekertaris Desa Nowa), pada hari senin, 23 Agustus 2021)

Beberapa kegiatan pemuda yang bertujuan membangun Sumber Daya Manusia untuk lingkup Pemuda Desa Nowa :

a. Membangun ruang lingkup diskusi produktif, dimana kegiatan ini dilakukan oleh lembaga kepemudaan untuk menambah wawasan dan pengetahuan pemuda dalam lingkup sosial, setiap pembahasan diskusi yang dibangun yaitu membahasan tentang nilai-nilai sosial kemasyarakatan, yang bertujuan untuk bagaimana pemuda dan regenerasi di desa nowa mampumenerapkan nilai-nilai sosial kemasyarakatan sehingga terjalinnya rasa persaudaraan dan emosional yang baik di lingkup kepemudaan. Sehingga mampu menekan angka kriminalitas di tingkat desa dan ruanglingkup pada umumnya;

b. Membangun lomba sepak bola semi futsal tingkat Kabupaten Dompu, lomba ini bertujuan untuk ajang silaturahmi dan 
pemanduan bakat untuk pemuda supaya pemuda mampu bangkit dari pengaruh buruk perubahan zaman. Yang mana perlombaan itu juga adalah sebagai pengalihan kegiataan kepemudaan di desa nowa yang tinggi dengan angka kriminalitasnya baik dari sisi Pergaulan Bebas, Peredaran Narkotika, Miras dan perjudian yang merajalela;

c. Pembinaan volly ball sebagai wadah pengembangan potensi untuk pemuda/pemudi ditingkat desa, sebab pemuda/pemudi desa nowa sangat meminati bidang olahraga ini. Sehingga potensi yang di miliki pemuda/pemudi dapat diasah dengan baik. (Hasil wawncara dengan tokoh pemuda Desa Nowa Ajunaffid. SE. (anggota karang taruna Desa Nowa), hari Sabtu, 27 Agustus 2021 bertempat di Rumahnya pada jam 16:30 WITA.

Ada bebarapa kegiatan yang dilakukan oleh aparatur keaman desa dalam menjaga ketertiban dan keamanan desa Nowa yaitu :

a. melakukan Sosialisasi Head to Head dengan seluruh masyarakat desa Nowa yaitu dengan memberikan arahan agar setiap orang tua tetap mengontrol setiap pergaulan anak-anak nya, dan selalu membimbing dalam lingkup keluarga agar tidak melakukan hal-hal yang tak diinginkan dan tidak menggagu ketertiban sosial. Waktu pelaksanaan Sosialisasi ini pun dilaksanakan hampir setiap hari ketika babinsa dan bhabinkantibmas keliling desa Nowa;

b. Memberikan pengarahan dan Bimbingan kepada pemuda desa Nowa, agar mampu menjaga ketertiban pergaulan tingkat pemuda sehingga terjalinnya rasa persaudaran dan kesatuan pemuda yang harmonis. (Hasil wawancara dengan Serda Sudirman (Babinsa Desa Nowa) dan AIPDA Dahlan (Bhabinkantibmas Desa Nowa) pada Hari Senin, Tanggal 23 Agustus 2021 pada jam 11:00 WITA, selaku sebagai aparatur keamanan desa Nowa)

Salah satu usaha penanggulangan kkejahatan tidak hanya telah kejahatan adalah menggunakan sarana menimbulkan penderitaan bagi korban hukum pidana, yakni dengan sanksinya dan masyarakat secara keseluruhan, yang berupa pidana, yang dalam hal ini tetapi juga menimbulkan penderitaan seringkali dipersoalkan sehingga menjadi terhadap pelanggar yang dipidana itu perdebatan yang sangat dikalangan ahli sendiri. hukum (pidana), baik dari kalangan teoritisi Berdasarkan pernyataan yang maupun praktisi hukum. Pada umumnya dikutip tersebut ingin dikatakan bahwa yang menjadi persoalan adalah efektivitas penanggulangan dan pengendalian penerapan sanksi pidana, baik dilihat dari kejahatan dengan menggunakan sanksi segi pelaku tindak pidana, korban (hukum) pidana, tidak hanya menyangkut kejahatan, maupun masyarakat serta dalam problem sosial, melainkan mencakup pula hubungannya dengan masalah ekonomis masalah kebijakan dalam menggunakan dari kejahatan. (Pratiwi Ayu Sri Daulat, 2018:81)

\section{KESIMPULAN}

Berdasarkan hasil penelitian diatas dapat disimpulkan Bahwa pertama Faktor yang mempengaruhi terjadinya kejahatan di desa nowa adalah tingkat pergaulan bebas pemuda, Pemanahan Secara Brutal, Penyebaran Miras dan Narkoba Yang merajalela, Perjudian Legal, dan Tawuran antara Pemuda. Kedua Peran Pemerintah Desa dalam menanggulangi kejahatan di desa nowa adalah dengan Melakukan sosialisasi tingkat dusun dan Memperkuat koordinasi antara instansi, baik dari pemerintah desa dengan aparat penegak hukum (kepolisian) serta tokoh pemudan dan masyarakat.

\section{SARAN}

Berdasarkan hasil penelitian ini, diperlukan tindakan pemerintah desa dalam melakukan penanggulangan terhadap berbagai kejahatan, seperti melakukan berbagai upaya pencegahan, sosialisasi, penyuluhan dan lainya, selain itu pemerintah desa harus bekerjasama lembaga penegak hukum, terutama polisi dalam menciptakan kamtibmas di Desa Nowa Kecamatan Woja Kabupaten Dompu.

\section{UCAPAN TERIMA KASIH}

Dalam pelaksanaan penelitian ini ucapan terima kasih terutama Ketua STIH Muhammadiyah Bima, yang telah membantu 
pembiayaan dalam penelitian ini, teman sejawat yakni dosen, Pemerintah Desa Nowa Kecamatan Woja Kabupaten Dompu dan Kapolsek Woja Kabupaten Dompu, masyarakat Desa Nowa serta semua pihak yang ikut serta dalam pelaksanaan penelitian ini.

\section{DAFTAR PUSTAKA}

Bambang Sunggono, (2003), Metodologi Penelitian Hukum, Jakarta, PT. Raja Grafindo Persada, Hal. 43

Djamal, S.F., (2019) Penanggulangan Kejahatan Dalam Perspektif Hukum Pidana Islam. Binamulia Hukum, http://dx.doi.org/10.37893/jbh.v8i2.86., Hal 230

Hasil Wawancara Dengan Bapak Ipda Zainal Arifin Kapolsek Woja Kabupaten Dompu, Pada Tanggal 10 Juli 2021).

Hasil Wawancara Dengan Bapak Muhammad Amin, S.sos. (Sekertaris Desa Nowa), pada hari senin, 23 Agustus 2021

Hasil wawancara dengan Serda Sudirman (Babinsa Desa Nowa) dan AIPDA Dahlan (Bhabinkantibmas Desa Nowa) pada Hari Senin, Tanggal 23 Agustus 2021 pada jam 11:00 WITA

Hasil wawncara dengan tokoh pemuda Desa Nowa Ajunaffid. SE. (anggota karang taruna Desa Nowa), hari Sabtu, 27 Agustus 2021 bertempat di Rumahnya pada jam 16:30 WITA.

Mukti Fajar ND dan Yulianto Achmad, (2010), Dualisme Penelitian Hukum Normatif \& Empiris, Yogyakarta, Pustaka Pelajar, Hal. 192

Muliadi, Saleh. (2015). Aspek Kriminologis Dalam Penanggulangan Kejahatan, Fiat Justisia: Jurnal Ilmu Hukum 6 (1). https://doi.org/10.25041/fiatjustisia.v6no1. 346.

Prakoso, Abintoro. (2013) Kriminologi Dan Hukum Pidana, Yogyakarta: Laksbang Grafika, Hal 79

Pratiwi Ayu Sri Daulat, (2018) Urgensi Penggunaan Sanksi Hukum Pidana Dalam Konteks Penanggulangan Kejahatan, Jurnal Ilmiah Hukum dan Dinamika Masyarakat, Vol 16, No 1 (2018), Hal 81
Soerjono Soekanto, (2014) Pengantar Penelitian Hukum, Hal. 25

Suharso dan Ana Retnoningsih, (2011), Kamus Besar Bahasa Indonesia, Cet. 10, Widya Karya, Semarang, Hal 196 